\title{
Mesenchymal Stem Cell
}

National Cancer Institute

\section{Source}

National Cancer Institute. Mesenchymal Stem Cell. NCI Thesaurus. Code C43423.

An undifferentiated stromal cell with the ability to develop into the cells that form distinct mesenchymal tissues; such as bone, muscle, connective tissue, blood vessels, and lymphatic tissue. 